\title{
Exploration of Sustainable Landscape in Iran: From Persian Garden to Modern Park
}

\author{
Honey Fadaie and Vahid Parhoodeh
}

\begin{abstract}
This paper concentrates on the result of research based on studies on parameters of sustainability in Persian Garden design as a traditional Iranian landscape and in a contemporary park, Jamshidieh in Iran as a new experience of re-creation of Persian Gardens' sustainable design. Since, sustainable development has three parts: social, economic and environmental. The complexities of each part are too great to discuss in a paper of this length, thus the authors decided to analyze the design of Persian garden by considering their environmental sustainability. The method of this research is descriptive- analytic based on documental resources and field studies. By the analysis of sustainable features and characteristics of traditional gardens, and exploration of parameters of sustainability in Iranian modern landscape, Such as Jamshideh Park, the main objective of this research is to identify the strategies for sustainable landscaping and parameters of creating sustainable green spaces for contemporary cities. The results demonstrate that in Persian Gardens, sustainable parameters such as productive networks and local renewable materials have been used to achieve sustainable development. At the conclusion, guidelines and recommendations for sustainable landscaping are presented.
\end{abstract}

Index Terms-Jamshidieh park, Persian garden, sustainable landscape, urban green space.

\section{INTRODUCTION}

The lack of urban green spaces in the $20^{\text {th }}$ century have had great impact on energy crisis and environmental disasters in our urban societies in 21th century. For that reason, the architects and urban planners forced to create sustainable green spaces in their cities. Today, a major contributing factor to increase pollution in Iranian cities is the use of non-standard and unsustainable models and neglecting climatic patterns in architectural design, where as in the past, historical Persian gardens and traditional landscape architecture of Iran, could respond to human comfort requirements. Studies show, these kind of green urban spaces in Iran, from the ancient time until nineteenth century, when Iranian designers began to embrace more modern design, have built according to sustainable features, thus the study on sustainable and physical aspects of these historical Persian gardens, could be considered as an appropriate model for today's design with respect to sustainability and energy saving. Based on historical findings and observations of

Manuscript received December 6, 2016; revised May 2, 2017.

Honey Fadaie is with the Department of Art and Architecture, Rudehen Branch, Islamic Azad University, Rudehen, Iran (e-mail: honeyfadaie@yahoo.com,h.fadaie@riau.ac.ir).

Vahid Parhoodeh is with the Department of Architecture, Larestan Branch, Islamic Azad University, Larestan, Iran (e-mail: vahidparhoodeh@yahoo.com).
Iran's existing historical gardens, the authors concluded that the model of Persian garden design is usually rectangular shape, surrounded by four walls and crossed by water canal, which flows inside the garden and through the main pavilion [1]. The main elements of Persian gardens which are nearly the same in all of them consist of natural elements, such as water and vegetation, and built elements, such as a pavilion, and walls. A Persian garden typically features a conceptual design, with the gardens natural and built elements organized around a central axis (Fig.1).

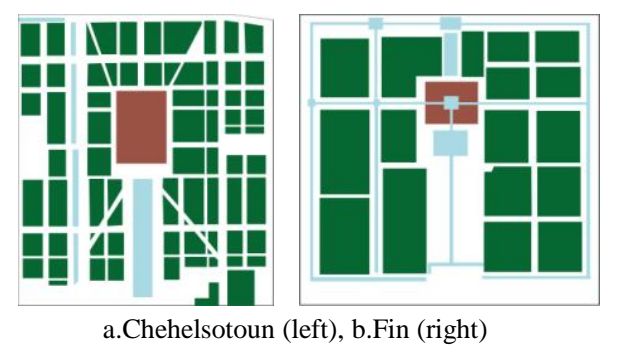

Fig. 1. Two models of historical Persian gardens.

\section{RESEARCH AND METHODS}

The main objective of this research is to identify the strategies for sustainable landscaping and parameters of creating sustainable green spaces for contemporary cities. In this research the main hypothesis is:

"The Parameters of sustainability in Persian Garden Design can be used as new strategies to create sustainable urban green spaces."

The research methodology of this paper is descriptive-analytical method, based on historical and documented sources and field studies. For data collections, the authors used two methods: library research and field study and this research framework include these processes:

-The description and analysis of sustainable landscape design.

-The exploration of parameters of sustainable landscaping in Persian Garden design

-The description of sustainable parameters in a new experience of re-creation of Persian gardens design.

\section{DESCRIPTION AND ANALYSIS SUSTAINABLE LANDSCAPE}

Ian Thomson believes that landscape architecture has three parameters; social, aesthetic, and ecologic. The ecologic parameter directly related to ecologic sustainability, thus the importance of sustainability in landscape design is understood [2].Sustainable landscaping is low impact, low maintenance, low resource use and frequency low-cost landscaping that fits each particular site and climate-virtually 
taking care of itself. Sustainable landscapes incorporate and balance the human desire for beautiful and functional landscape with the imperative to valuable resources [3]. The main important principles in sustainable landscape design are:

- Use landscaping to conserve energy and prevent air pollution [3].

- Design appropriate irrigation systems for efficient water use.

- Water conservation to limit potable water use.

- Choosing indigenous plant and use the right plant in the right.

- Consumption of natural and renewable resources and materials to conserve energy.

- Avoid/reduce chemical fertilizers and pesticides to prevent land pollution [3].

Since in the landscape architecture the main elements consist of natural elements (water and vegetation) and built elements, thus the principles and parameters of sustainability in the mentioned elements are discussed here:

\section{A . Water and Irrigation System}

Water conservation is an essential factor in sustainable landscape design. Prevent water loose and using different methods to reduce water loss via evaporation. Also, group of plants that have similar water requirements, the tendency is to accommodate those plants with the higher needs [4].

\section{B. Vegetation and Planting}

One way of exploring possible climate adaptations is to the green infrastructure of contribution from the perspective of landscape ecology. The different components of the green infra structure play different roles in their climatic adaptation. Selecting appropriate types of native vegetations and planting them according to water irrigation are sustainable approaches to working with landscape vegetation [5]. Also, productive plants and fruitful trees are key ingredients to achieve sustainable landscape and today, they are considered as continues productive urban landscape. Scale of productive plants include a wide scope of suburban areas, recycled realms, urban parks, urban corridors, facades and roofs, private and collaborative gardens, small courtyard of residential, window sides and terraces [6].

\section{Built Elements and Hard Materials}

The best way to consider the sustainable use of resources and materials within a designed landscape is to think of site as functioning system, with inputs and outputs of resources, and internal cycling. Unsustainable systems tend to be open that is they require high resources input, minimize internal cycling, and replace negative outputs such as storm water; while sustainable systems are closed systems, reduce resources inputs by using local and renewable materials, and have efficient outputs, such as clearer water, less waste of material and etc. [5].

\section{THE PARAMETERS OF SUSTAINABLE LANDSCAPING IN PERSIAN GARDEN}

As it was mentioned Persian garden consists of natural and built elements. Natural elements of Persian garden; water and vegetation are key ingredients, act as natural cooling devices in these Gardens, and also they have had effective role to create Persian garden as sustainable landscape especially in arid regions. Furthermore, in Persian gardens, built elements, such as pavilion, were constructed according to sustainable model of design. The strategies and parameters of sustainability in Persian garden's element will be discussed in below:

\section{A. Types of Water Display and Irrigation System}

The lack of water in such arid regions required the designers of Persian Gardens to create sustainable methods for irrigation and water displays. The irrigation system influences the geometrical design of the garden, thereby preventing the waste of water [7]. The extent of Persian garden depends on the amount of water, and the garden designer creates microclimate, by channeling breezes over water to reduce air temperature and increase weather humidity. The source of water in the most Persian gardens is qanat. Qanat is an indigenous method of irrigation that was invented by ancient Iranians to carry water from mountain beds through interconnected wells, creating underground streams and transporting water to far-off places (Fig. 2). After the water irrigates the trees and other plants in each garden, it flows outside the garden to irrigate farms and other lands. There are many ways to display water in a garden. Each way, in turn, has its own effect on sustainability (Fig.3).

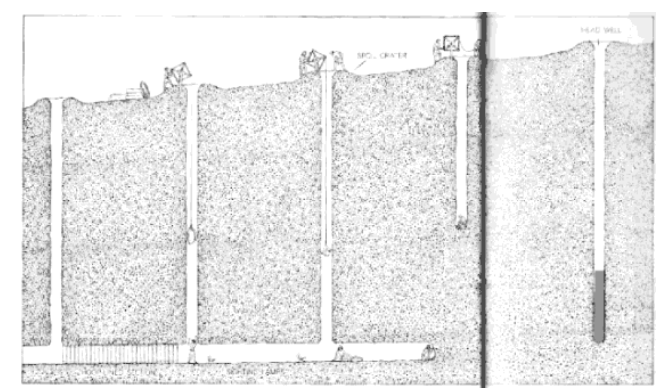

Fig. 2. The irrigation system by qanat.

Large pools and ponds store water for drought seasons, while canals and streams irrigate plants and, Fountains and cascades are used for beautification of gardens and increase weather humidity during hot days.

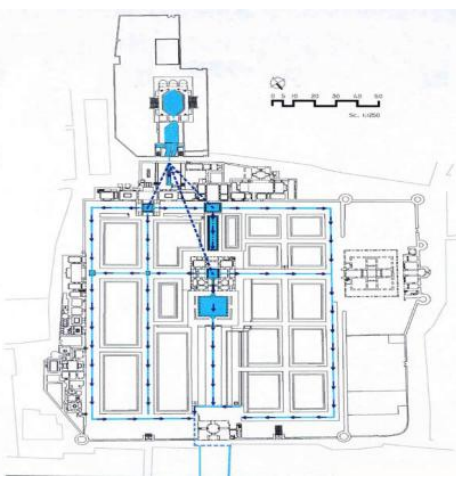

Fig. 3. Corresponding the irrigation system to geometrical form of garden, after irrigation the garden, the water flows outside to irrigate other lands( Fin Garden, Kashan).

In Persian gardens, vegetations perform functions, such as; create an architectural framework, produce aesthetic effects and modify the microclimate [8]. Vegetations guide and filter the breeze and increase evaporative cooling. By placing vegetation strategically, designers are able to provide shade 
and absorb the sun's ultraviolet can direct the wind and alter the microclimate. In addition, plants modify the climate in three ways; wind control by guide and filter the breeze and ultimately cause to increase evaporative cooling, modification of sunlight and change the moisture [8].In these gardens, excluding the central axes, on which each garden's pavilion is located; the entire garden is covered by vegetation. Evergreen trees used as shading devices and also, protection from storms and local dusty winds. Evergreen trees are located in the main passageways, while fruit trees are located between them. Persian gardens are able to support fruit trees due to their sustainable features, including geometrical designs and economical use of water through irrigation systems(Fig.4). A large number of trees are planted for the sake of shade, and as a result the garden contains narrow walks [9]. In Persian garden, many kinds of evergreen and fruit full trees are used for different reasons; they are used to moderate local climatic conditions, eating and also some of them are used as medicine for many disease' treatment. Moreover, Persian gardens typically feature a type of clover called spest. Spest has very sustainable characteristics; it absorbs nitrogen from the air and transports it to the soil, repels insects, is easy to maintain, requires less water than grass, and can be used as cattle feed during cold seasons [10]. According to these characteristics, the authors can conclude that, the planting system in Persian garden design is corresponding to different parameters of sustainability.

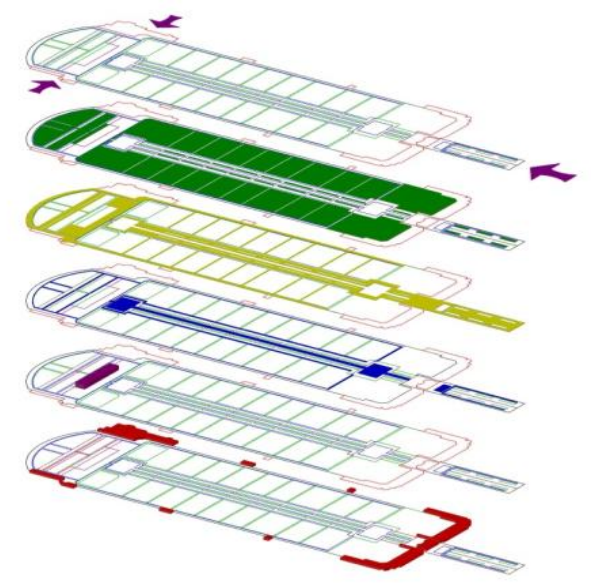

Fig. 4. Corresponding the Irrigation, Planting systems to garden's geometrical form (Shazdeh garden).

\section{The Main Built Elements of Persian Garden: Wall and Pavilion}

Wall is recognized as the built element in Persian Garden, which all the garden's elements are surrounded by it. The wall has not only the security role to protect the garden from enemies attacks, but also protect the garden against hot dusty winds, preserve the humidity inside the garden [7].

Furthermore, wall acts as shading devices inside the Persian garden by creating the shadow. Another main building which is nearly the same in all Persian gardens is pavilion. Since the Persian gardens acts as microclimates in arid regions, the gardens' pavilions are the only extroverted buildings, Perhaps due to the amounts of vegetation and water that is used in Persian garden to create a microclimate, where as other traditional Iranian buildings in hot and arid climates are introverted buildings. In Persian garden, a close relation with the nature is obtained in simple manner and there is no interval and boundary line between the pavilion and the rest of garden, so that it cannot be seen where one begins structure to the garden. The balcony is an isolated part of the pavilion. Typically, the balcony offers a panoramic view of the garden, yet remains invisible to the eyes of strangers in the garden [11]. Since the most Persian gardens are located in arid regions of central plateau of Iran, passive cooling is the main strategy to achieve a sustainable and comfortable space. The most important strategies for passive cooling in these buildings design in arid regions are providing shade and natural ventilation by wind and water. Iwan and balcony are semi-closed spaces of Persian gardens' pavilions. An Iwan is a single vaulted hall, which is opened to the outside and acts as an entrance space for pavilion, connecting the outside and inside of the pavilion.

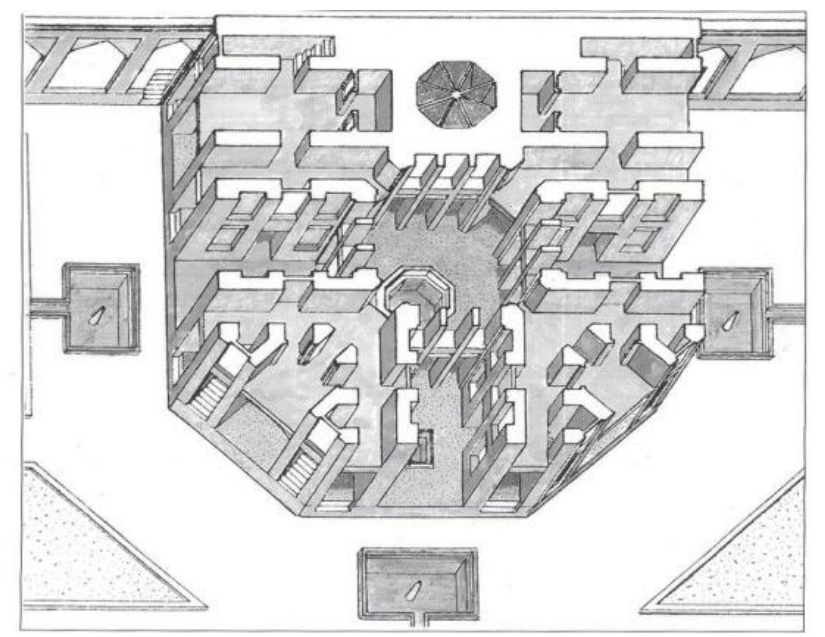

Fig. 5. Dolatabad Pavilion with its balconies, Iwans and water ponds inside the building.

The use of shading devices is an important strategy in sustainable design. Shading devices should be designed to reduce direct solar radiation and prevent reflection onto any part of the building or through any opening [12]. Also, the placement of water ponds inside the buildings is the main passive cooling strategy in Persian gardens' pavilions design to increase weather humidity (Fig. 5). Another important factor in pavilion design is choosing materials. In Persian gardens, the main pavilions' materials are usually; brick, tile, adobe which are found easily in central plateau of Iran, They have high thermal resistance, and high thermal capacity. Also, they are good at absorbing solar radiation [12].

\section{The Relationship between Garden and Urban Fabric}

Today in some cities, productive urban network is considered as an appropriate strategy to achieve sustainable development. The integration of productive urban network as a green layer to the urban fabric is a reason to increase the quality of environmental biology, and provides food for inhabitants [13].In Iran this strategy and method of planting has had a historical background in their garden cities. At the first time, the model of garden city was built in 6BC by ancient Iranian emperor Cyrus the great. This method of design, gradually developed especially in $17^{\text {th }}$ century during Safavid era, and at that time the most important cities such as Isfahan, Qazvin, and Shiraz became garden cities, which productive fruitful gardens became as parts of their urban infra structure (Fig. 6). 


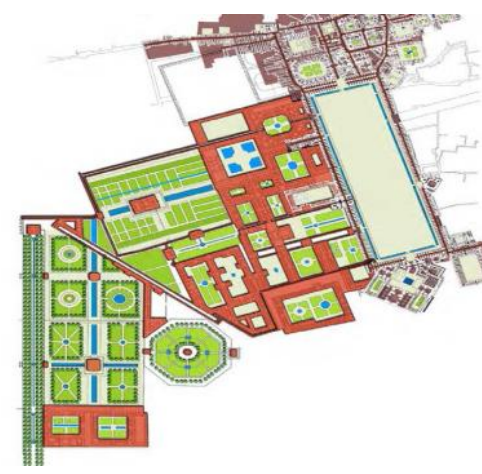

Fig. 6. The connection of gardens to public spaces of city in garden city of Isfahan.

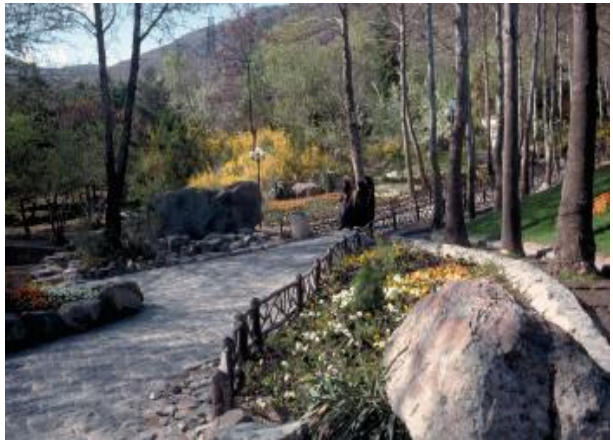

Fig. 7. Jamishideh Park, located in the mountain.

\section{DESCRIPTION OF SUSTAINABLE PARAMETERS IN A NEW EXPERIENCE OF RECREATION OF PERSIAN GARDEN}

\section{A. Jamshidieh Park}

Jamshideh Park, reconstructed as a public garden in 1978, is an example of the natural mountainous garden (Fig.7). The Jamshidieh stone garden incorporates concerns for sustainable development. The focal points have presently been identified to prevent and control the city's destructive encroachment on nature. Using sustainable and non mechanical devices, water will be channeled from valleys as the optimal irrigation method to develop green space. For landscaping, scattered loose rocks were used to create natural waterfalls, terraced enhancements, streambeds, and paving. Existing trees were preserved and new ones added. Also, native vegetations of mountainous regions will be identified and cultivated (Fig.8) [14].In modern Tehran, which its rapid expansion is a serious danger to the ecological and natural heritage, surrounded the city, Jamshideh Park with its different types of plants and birds acts as a semi-closed ecosystem, and can be introduced as a sustainable urban landscape in Tehran. The main parameters and principles of sustainable design in Jamshidieh Park are:

-Conservation of old elements such as a large pool for water storage during the draught seasons, and also old trees planted in the main axes.

1) Planting evergreen trees such as pine and cypress in the main axes of Park.

2) Planting fruitful trees in the three parts of the park.

3) Maximize use of water by appropriate irrigation system, by using main channels.

4) Increase weather humidity by using water channels and cascades.

5) Design each zone of park according to its natural potentials and elements.

6) Using stone as a local material, by select it from the mountainous bed and nearest stones mine [14].

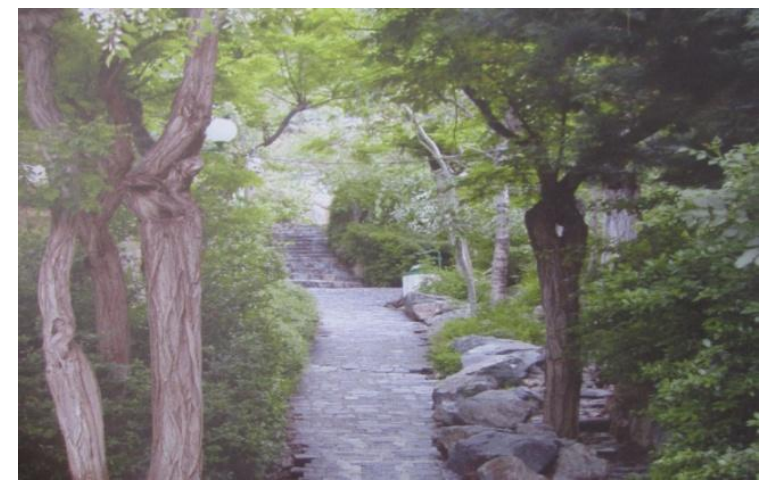

Fig. 8. The main axis of Jamishideh Park with the old trees and stone pavement.

\section{RESULTS}

As it was discussed, the parameters and principles of Persian Gardens design like accordance the garden with its context, relationship between the garden and urban fabric, usage of shading and fruitful trees, preventing waste of water, use indigenous renewable materials, are the main strategies to achieve sustainable landscape. Today, in some new urban green spaces of Iran, like Jamshidieh Park, the mentioned parameters can be found. Therefore, these results confirm the hypothesis of this paper: The Parameters of sustainability in Persian Garden Design can be used as new strategies to create sustainable urban green spaces.

\section{CONCLUSION}

The purpose of this paper is to determine various aspects of Persian gardens' design according to sustainable landscape architecture, and also the possibility of these aspects and parameters in today urban landscape. Due to climatic factors, Persian gardens in arid regions utilize natural soft and hard landscaping. Today, landscape architecture has a special role to link between the society and natural environment. So, sustainability is unavoidable factor in contemporary urban design. Based on analyses of Persian gardens' natural and built elements, the authors conclude that it is possible for current practicing architects to create sustainable landscapes in today cities by these strategies:

-Protection of natural environment such as, valleys, water beds, green spaces in the urban context.

-Creation of ecologic infra structures by using the models of sustainability, as it was discussed in this paper.

-Creation of productive urban network as a part of urban structure in the cities.

-Use renewable vernacular soft and hard materials in landscape design.

\section{REFERENCES}

[1] M. Alemi, "Chahar bagh," Environmental Design: Journal of the Islamic Environmental Design Research Centre1, pp. 38-45.1986.

[2] A. Shahcheraghi and M. Hamidpour, "The exploration of ecologic sustainability in landscape architecture," Iranian Journal of Jostarhay-e-Shahrsazi, vol. 9, no. 35, pp. 18-26, 2011. 
[3] M. Rosen. Sustainable Landscape. New Jersey Department of Environmental Protection. [Online]. Available: http://www.epa. gov/ green spaces. 2007.

[4] J. Bousselot, K. Badertscher, and M. Roll. Sustainable landscape. [Online]. Available: http://www.ext.colostate.edu/pubs/garden/07243

[5] J. F. Benson and M. Roe, "Landscape and sustainability," Routledge, New York, pp. 197-198, 2007.

[6] M. Sheibani and S. Chamanara, "Productive urban network as a strategy for achieving sustainable development," Iranian Journal of Manzar, no. 20, pp. 18-23, 2012.

[7] A. Shahcheraghi, "Paradigms of paradise, recognition and recreation of the Persian garden," Tehran, pp. 70-80, 2010.

[8] N. A. Leszczynski, Planting the Landscape; A Professional Approach to Garden Design, New York. Jhon Wiley and Sons Inc Publishers, 1997.

[9] Y. Daneshdoust, Islamic Gardens in Iran: In Les Jardins De I'islam, ICOMOS. Paris.1993.

[10] E. Zamani, M. Leylian, A. Amirkhani, and H. Okhovat, "Recognition and analyses of Persian gardens elements with respect to ethical principles," Iranian Journal of Bagh-e-Nazar, vol. 6, no. 11, pp. 25-38, 2012.

[11] M. Gharipour, "Pavilion structure in Persianates gardens reflection in Thetextual and visual," Ph.D. dissertation, Georgia Institute of Technology, pp. 137-142, 2009.

[12] H. Fadaie and S. M. Mofidi, "The effect of environmental sustainability in the architecture of Persian garden's pavilion," in Proc. $5^{\text {th }}$ SAS-Tech Symposium, Mashhad, Iran, pp. 1-8, 2011.

[13] G. Paban-Hazrat, Design in Nature, Tehran Ferdowsi Garden, Jamshidieh Garden, Tehran, Ch:8. 2009.
[14] G. Pasban-Hazrat, "Sustainable development in Tehran, sustainable landscape design in arid climates," in Proc. Jointly Organized by the Aga Khan Trust for Culture, pp. 39-47. 1996.

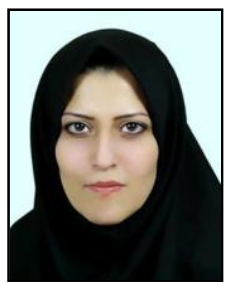

Honey Fadaie was born in Tehran, Iran. She has been a faculty member of Department of Art and Architecture, Rudehen Branch, IAU since 2008. She is Ph.D from Department of Art and Architecture Science and Research branch, Islamic Azad University (IAU), Tehran, Iran. Her research fields for sustainable architecture and landscape in Hot (arid and tropical) climates and her Ph.D thesis is" Iranian Gardens in Arid Regions from Sustainable View".

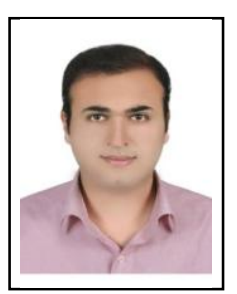

Vahid Parhoodeh was born in Shiraz, Iran. He has been a faculty member of Department of Architecture, Lar branch, IAU, Lar, Fars province, Iran. He is Ph.D from Department of Art and Architecture Science and Research branch, Islamic Azad University (IAU), Tehran, Iran. His research field for traditional Iranian architecture. 